\title{
Preventing Bladder Injury at Hysterectomy in Post-Cesareans
}

\author{
Shikha Seth* and Arun Nagrath \\ Department of Obstetrics \& Gynaecology, UP University of Medical Sciences, India
}

Submission: February 05, 2017 ; Published: March 21, 2017

*Corresponding author: Shikha Seth, Department of Obstetrics \& Gynaecology, UP University of Medical Sciences, Saifai Etawah, 206130, India, Tel: 9411850238; Email: drseth_shikha@yahoo.com

\begin{abstract}
With the increasing cesarean section rates gynecologists are facing more number of cases with previously scarred uterus at the time of hysterectomy. Uterine incision especially of cesarean section leads to bladder adhesions which poses great problem at the time of bladder dissection during hysterectomy and sometimes inadvertently ends up in cystostomy. Greater the number of cesareans, higher is the chances of adhesions and fibrosis. Both vaginal and laparoscopic approach can be utilized effectively just taking few precautions. Urinary bladder if gets injured, one should be able to diagnose it per operatively so that timely management can be done to prevent long term squealae. Here few important points are focused which can help in assessing the difficulty, at risk cases pre-operatively and surgical options to prevent bladder injury at the time of both vaginal and laparoscopic hysterectomy.
\end{abstract}

Keywords: Previous cesarean section; Bladder injury; Hysterectomy; Cystostomy; Scarred uterus

Abbreviations: CS: Cesarean Section

\section{Introduction}

With the modern medicine, equipments, awareness altogether with the consumer protection act the cesarean section is facing rising trend ranging from $20-30 \%$ deliveries in most of the centers. Now a days Gynecologist are getting most of the patients of hysterectomy who have undergone one, two or sometimes even three cesareans in the past. The problem arises due to post-surgical adhesion which makes the otherwise normal size uterus hysterectomy technically difficult vaginally, requiring either the abdominal or laparoscopy procedure. Previous cesarean section (CS) is a significant risk factor for urinary tract injury at hysterectomy (odds ratio 2.04; 95\% CI 1.2-3.5). Incidental cystostomy at time of abdominal and vaginal hysterectomy was $0.76 \& 1.3 \%$ respectively [1].

Mobilization of urinary bladder off the cervix is the 2nd important step after securing the cornual pedicles. In cases of scarred uterus adhesions are there not only between the bladder and uterus but also to the anterior abdominal wall which make the dissection challenging. To avoid complications lateral window technique is the safest option whether the vaginal, abdominal or laparoscopic mode is chosen. This mini-review focus on surgical considerations to avoid bladder complications during hysterectomy in the scarred uterus cases.

\section{During Vaginal Hysterectomy}

Conventional procedure of vaginal hysterectomy describes emptying the bladder before surgery with catheter to avoid injury, but in cases of previously operated uterus it is preferable to keep the post void urine to be left in urinary bladder as it better delineates the boundaries and in case of inadvertent injury results in gush of urine for intra-operative identification. Urinary bladder extent ideally be noted by the bladder sulcus (the bladder reflection on the cervix) and should be confirmed by the bladder sound pushed through urethral meatus.

Submucousal fluid infiltration is recommended using $100 \mathrm{ml}$ saline $(0.9 \%)$ or antibiotic solution with local anaesthetic (0.5$1 \%$ lignocaine) and 1:2,00,000 adrenaline or 20 units vasopressin injection, which reduces the blood loss by compressing and constricting the vessels keeping the surgical field clean for dissection purpose. Saline takes the path of least resistance and separates the planes, lyse filmsy adhesions, pushes the bladder up, while anesthetic relaxes the pelvic floor further.

Traction and counter traction mechanism be used judiciously to achieve the exposure of vesico-cervical junction for the incision in vaginal approach. Surgeon pulls the cervix down toward himself with his left hand while the assistant 
pushes the anterior vaginal wall with bladder up and cephalad. Sharp dissection is preferred while dissecting between the two viscera as it maintains surgical planes. Blunt dissection in case of previous scar has high chances of cystostomy. Keep the scissors tip towards the cervix while dissecting. In cases of nulliparous women and limited intorital opening "Schuchartd's incision" (gynaecological episiotomy) can be tried to improve exposure.

Surgical complication with vaginal hysterectomy in one or two previous cesearenacses do not differ in hands of experienced person with proper patient selection [2] and uterine scarring as sequel to cesarean is not a contraindication to vaginal hysterectomy [3]. Restricted mobility, cases with high up cervix which cannot be pulled even one centimeter on pulling with volsellum, which in draws abdominal wall with pulling are highly suggestive of abdominal wall adhesions and should not be tried overzealously by the beginners [4].

For laparoscopy the $10 \mathrm{~mm}$ central optical port three $5 \mathrm{~mm}$ accessory ports are placed after creating pneumoperitoneum. Abdominal wall adhesions are found in midline and are tackled with cautery or harmonic dissection. Bladder when densely adherent to lower segment poses difficulty in pushing it down. Safe approach is Lateral Window Technique.

\section{Lateral window technique: can be used both for vaginal and laparoscopic approach to hysterectomy}

This space was first described by Dr. Shrish Sheth utilizing the utero-cervical broad ligament in post cesarean cases during vaginal hysterectomy. He described that the lateral area; the two leaves of broad ligament remains free and allows easy possibility for entry to dissect whether vaginally or abdominally. In vaginal hysterectomy cervix is pulled down and bladder cephalad by the assistant and instead of pushing the bladder up from the center using gauze covered thumb, sharp dissection using blunt curved Metzenbaum scissors is done from lateral to medial side keeping the tip of scissors near as well as towards the cervix. Bladder pillars are incised from lateral to medial side. 220 vaginal hysterectomies with previous cesarean reported by Dr Sheth [4] with only $1.5 \%$ intra-operative urological trauma vaginally.

In laparoscopic approach after cutting the cornual pedicles broad ligament is dissected down till the uterine bundle is identified. Once the uterine vascular bundle is identified the space can be dissected just above these vessels to reach the lateral margins of cervix. Any fatty tissue should be moved with the bladder. Uterine vessels are then tackled by desiccation or ligation. Similar procedure is done on the opposite side. Once the bladder is completely dissected and lifted off from the cervix below, midline adhesions of the bladder and pillars can be gradually separated using sharp dissection or harmonic ultracision staying near to cervix $[5,6]$.

The lateral approach crates a window which allows a safe dissection. It is unlikely that the scar of the previous cesarean would extend laterally with thickness as in the medial portion. In few cases adhesions may be very dense then intraoperative retrograde distension of baldder with Methylene blue dye may help in identifying the borders. This helps in delineate the injury avoiding the need of cystoscopy [7].

\section{Conclusion}

Both Laprascopic and Vaginal hysterectomy are safe and feasible procedures in patients with previous CS, where laparoscopy is associated with reduced blood loss and hospital stay, vaginal is associated with reduced surgery time without abdominal wound [8].

\section{References}

1. Rooney CM, Crawford AT, Vassallo BJ, Kleeman SD, Karram MM (2005) Is previous cesarean section a risk for incidental cystotomy at the time of hysterectomy? A case controlled study. American Journal of Obstetrics and Gynecology 193(6): 2041-2044.

2. Poindexter Y, Sangi-Haghpeykar H, Poindexter A, Thomakos N, Young $R$, et al. (2001) Previous cesarean section: a contraindication to vaginal hysterectomy? J Reprod Med 46: 840-844.

3. Boukkerou M, Lambaudie E, Collinet P, Crepin G, Cosson N (2003) A history of cesareans is a risk factor in TVH. ACTA Obstet Gynecol Scand 82: 1135-1139.

4. Sheth S, Malpani AN (1995) Vaginal hysterectomy following previous cesarean section. Int J Obstet Gynaecol 50(2): 165-169.

5. Chen SY, Namgung S, Choi J (2007) A method to prevent bladder injury invlaparoscopically assisted vaginal hysterectomy (LAVH) for patients with vesico-cervicla adhesions. J Minim Invasive Gynecol 14(6): 114116.

6. Unger JB, Meehs GR (1998) Vaginal hysterectomy in women with history of previous cesarean delivery. Am J Obstet Gynecol 179: 298299.

7. Wang L, Merkur H, Hardas G, Soo S, Lujic S (2010) Laparoscopic hysterectomy in the presence of previous caesarean section: a review of one hundred forty-one cases in the Sydney West Advanced Pelvic Surgery Unit. J Minim Invasive Gynecol 17(2): 186-191.

8. Moez K, Jad D, Marwen B, Monia F, Fethi Z (2015) Hysterectomy in Patients with Previous Cesarean Section: Comparison between Laparoscopic and Vaginal Approaches. A Prospective Randomized Controlled Study. Donn J Med Med Sci 2(7): 103-107. 
(C) This work is licensed under Creative DOI: $10.19080 / J G W H .2017 .03 .555610$
Your next submission with Juniper Publishers will reach you the below assets

- Quality Editorial service

- Swift Peer Review

- Reprints availability

- E-prints Service

- Manuscript Podcast for convenient understanding

- Global attainment for your research

- Manuscript accessibility in different formats

( Pdf, E-pub, Full Text, Audio)

- Unceasing customer service

Track the below URL for one-step submission https://juniperpublishers.com/online-submission.php 